\title{
Managerial Skills for Engineers, an optative subject on last course of grade in the ETSIIV. Results of applying new methodologies for developing managerial skills
}

\author{
Carlos Manuel Dema Perez ${ }^{\mathrm{a}, \mathrm{b}}$, Carlos Fernández Llatas ${ }^{\mathrm{a}, \mathrm{c}}$, Antonio Martinez- \\ Miñana $^{\mathrm{a}, \mathrm{d}}$, Sofía Estelles-Miguel ${ }^{\mathrm{e}}$ \\ ${ }^{a}$ ITACA-Research-Group, Universitat Politècnica de València, camino de Vera s/n, 46022 Valencia

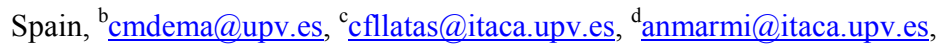 \\ ${ }^{\mathrm{e}}$ Departamento de Organización de Empresas (DOE). Universitat Politècnica de València, camino de \\ Vera s/n, 46022 Valencia, Spain, soesmi@omp.upv.es
}

\begin{abstract}
Managerial Skills for Engineers is an optative subject placed on last degree course. Students have passed on second course "Organization Foundations" as only subject about management contents. So, it was proposed with the aim of developing main managerial skills thinking of their professional future, highlighting among them communication skills clearly. On fact, during quotidian engineer's work on plant they need leading groups, participating on meetings, negotiating with clients, suppliers, etc. Communication constitutes a basic pillar for personnel and professional engineer's future success. In this paper most relevant results reached during three last years have been gathered up, all of it considering actual constraints have advised us to improve each year step by step consolidating each one before moving forward.
\end{abstract}

Keywords: Lorem, ipsum, dolor, sit.

\section{Introduction}

Managerial Skills for Engineers is an optative subject placed on last degree course. Students have passed on second course "Organization Foundations" as only subject about management contents. So, it was proposed with the aim of developing main managerial skills thinking of their professional future, highlighting among them communication skills clearly. On fact, during quotidian engineer's work on plant they need leading groups, 
Managerial Skills for Engineers, an optative subject on last course of grade in the ETSIIV. Results of applying new methodologies for developing managerial skills

participating on meetings, negotiating with clients, suppliers, etc. Communication constitutes a basic pillar for personnel and professional engineer's future success.

It's important to highlight this group's students are not typical engineering students, usually not too much interesting on personal skills and psychologic and sociologic issues. On the contrary, they have chosen this subject among other of technological shape, what shows their interest about these issues. Moreover, it's known that this subject implies a high level of homework and a constant rate of study lengthwise the only eight class weeks, what makes impossible to study only before the exam. Consequently, it is possible to plan the subject as a seminary assuming students have studied notebook and made basic exercises, including on it, before class.

In addition to classical contents and exercises about high effective teams, negotiation, meetings, conflicts, interpersonal an written communication more relevant issues are assertiveness, transactional analysis, meeting, conflicts and negotiation. By other side, students fill different questionnaires about the issues included on the subject syllabus. Process of translating these contents from company training actions to a grade is being a complex process by two main constraints: perceived application horizon, and available time for developing tools practicing them in order to apply them nearly automatically.

\section{Current subject schedule after three years of continuous improvment}

Early two weeks are dedicated to overhaul main contents of "Organization Foundations" passed on the second course of degree (Robbins, Judge \& Judge, 2008) (Robbins \& Coulter. 2008), a subject common to all engineering degrees. On first class session students answer a questionnaire about: system modelling, portfolio interpreting, motivation and leadership. Its aim is to know theoretical and practical knowledges that students actually keep back two years after having passed Organization Foundations. In light of the results of this first subject part contents would change adapting the cases or their development. On this questionnaire motivation model of Hackman \& Oldman and leadership model of Hersey \& Blanchard receive special attention since they will develop an important role in some cases that will be resolved afterwards.

Table 1. Number of questions on initial questionnaire about Management knowledge.

\begin{tabular}{|c|c|c|c|}
\hline & \multicolumn{2}{|c|}{ Question's number } & \\
\hline Basic concepts & 10 & 5 & Leadership \\
\hline System modelling & 5 & 4 & Hackman \& Oldman \\
\hline Portfolio interpreting & 5 & 4 & Hersey \& Blanchard \\
\hline Motivation & 5 & 2 & Decision taking \\
\hline
\end{tabular}


Three last year's results have driven us to utilize two first weeks of class to overhaul concepts, models and tools applying the method of case. This cases are proposed as homework and they have to resolve before class for finishing them in class working in group. In this way it is possible avoiding to waste class time explaining all contents again, and focussing time only for resolving complex or difficult of understanding points, and applying them. Moreover, it's an interesting opportunity for practising and evaluating the transversal competencies of self-learning, information search and public presentations.

First practice complements these cases working three transversal competencies: self-training, information searching, and report writing. Students form groups of four members with the task of preparing a power-point presentation, the notes for explaining a theory or model and an original example. Really, this practice has as aim to take a hard decision in which they will have responsibilities. For doing it all documents are placed on a common folder that will be closed until the valuation session. Each group will assess his work and what other groups have made, being group score the average of classmates scores. This assessment is made on class and everyone at the same time. Afterwards the folder will remain open and the information shared. If difference against professor score is minus than 1,5 points this average will be the final score. In other case will be the proposed by professor minus one point. In this way competences of coo-evaluation and selfevaluation are worked and assessed and overall the decision making with responsibility over results. Both written work as oral presentation are assessed with the support of two specific rubrics. In a practice session groups perform their oral presentation having as audience their classmates. Insomuch as group number is limited only there would be two groups doing the same work avoiding possible copy problems and with two simple forms is possible gathering all the information and standardize the process of scoring group works.

Students are no used to make decisions with the constraint of being accurate on their assessments. In this case if they don't evaluate correctly, they may handicap their classmates. So, first thing they ask for are clear criteria for assessing and examples of guide. But these tools are given only if students ask them for. Depending on time available they have to define an agreed upon criteria based on scales that could be applied by professors and students. They are spurred to define a good set of criteria in order to limit assessment value dispersion. This process usually is made on a practice session and it makes able to develop several transversal competencies: team work, auto-evaluation, cooevaluation, information search, decision making, etc.

Second part of subject deals about communication with the aim of improving student capacities and abilities on this field (Abbey, 1973) (Tubb 6 Carter, 1978) (Page, 1995) (Pfeiffer, 1999) (Phillips, 2003) (Potts \& Potts, 2013). Interpersonal and written 
communication focuses the effort. Informs, e-mails, and internal notes shape the axis of second part. In relation with the first one not verbal communication and the use of tools of assertiveness, transactional analysis and Johary Window, and their combinations, on daily activity constitutes the main axis of development. Classroom practices are focussed on exercises and short cases. Second practice session deals a full case of communication is resolved and presented. Video shows different situations that groups have to analyse and modify the dialogs applying subject contents in order to attaint defined goals. Logically first step consists on defining what tools to apply, how, in which order, and justify it. On presentation session trainers take one of the roles and the group members have to answer applying subject contents, basically assertive techniques. So students have to prepare different alternatives to face different answers.

Finally, third part deals contents of teams, meetings, conflicts and negotiation applying Harvard methodology (Coleman, Deutch \& Marcus. 2014) (Fisher \& Ury, 2012) (Lamber \& Myers, 1999) (Churchman, 1998) (Raiffa, 2003) (Sing, 2008).

General Target of this part consists on providing students principles, guide lines and tools for becoming to be an efficient member of a team and to participate with effectiveness on meetings and to prepare them. Since these two activities are an important activity of every engineer when begins to work in a company. Contents linked to meeting chairman and team leader remain on background and the schedule paid less attention so these usually are not needs on first years of professional activity. Afterwards they will be trained for developing these activities. In any way on theory main contents are developed and on class practices some students play the team member roles an others team leader role o meeting chairman. A similar approach has been developed with conflict resolution and negotiation. Considering the conflict as something natural in the organizations and on personal life whose problem is not the way of tackling it, and that negotiation is a daily activity of everyone and every time, both on personal and professional areas.

Third, and last practice, deals about resolving a case based on a real problem. Group work will be exposed asking for a tutorial session four weeks after finishing classes. Groups are of five people and their composition is free but the addition of Belbin profiles has to give a reasonable balanced profile. Aside from own case resolution score what is really important is the answer to a questionnaire in which students explain communication, groups, conflict, and negotiation tools applying alongside group work, assessing their practical utility, errors and successes and what they have learned with the experience. This part is made individually and hand written. Next year all this information will be supported on a spreadsheet EXCELL with the aim of studying statistically the results. 


\section{Main results of this teaching methodology}

At this point we are going to expose average values of questionnaires that students fill at the end of the subject before knowing their scores. These questionnaire has been developed on an EXCEL spreadsheet and it is delivered by e-mail. It is filled voluntarily and anonymously, so it can be considered a faithful reflect of their true opinion. In any case we consider it is a better evaluation tool than the final score and the questionnaire of satisfaction common to all the subjects in the University, over all in order to have true information for improving continuously.

Questionnaire is composed by four parts. Each one of them tackles one of subject areas and the last one resumes of students' perception about their capacities an abilities development. Below are shown the results, on average, of three last years.

\subsection{Review and extension of contents of Fundamentals of Organization applying case method.}

As is possible to check students consider they have advanced clearly on their capacity for applying concepts and tools already known. It seems clear that two years more provide a maturity they could not have then and, moreover, on the last degree course they perceive closer the application horizon. In any way what is more relevant is their opinion about the experience of taking a decision that may have consequences over other people. Logically they think it has been a hard experience and that would have preferred nor to have to take it. But, from the point of view of developing abilities and capacities about taking decisions the fact of considering the possible consequences adds to the correct way of applying the tools the feeling of living an uncomfortable situation and the need of accurating. 
Managerial Skills for Engineers, an optative subject on last course of grade in the ETSIIV. Results of applying new methodologies for developing managerial skills

Table 2. Students perception over Organization Foundations review applying the case method.

Three year's average values

\begin{tabular}{|c|c|c|c|c|c|c|}
\hline & Srongly agree & Agree & Neutral & Disagree & $\begin{array}{l}\text { Strogly } \\
\text { disagree }\end{array}$ & NA \\
\hline Do you agree this way of teaching the subject? & $95,12 \%$ & $2,44 \%$ & $0,00 \%$ & $0,00 \%$ & $0,00 \%$ & $2,44 \%$ \\
\hline \multicolumn{7}{|c|}{ Do you think you have improved clearly your knowledge and capacity of applying?: } \\
\hline System modelling & $87,80 \%$ & $10,98 \%$ & $0,00 \%$ & $0,00 \%$ & $0,00 \%$ & $1,22 \%$ \\
\hline Portfolio models assessment & $74,39 \%$ & $24,39 \%$ & $0,00 \%$ & $0,00 \%$ & $0,00 \%$ & $1,22 \%$ \\
\hline Motivation & $92,68 \%$ & $7,32 \%$ & $0,00 \%$ & $0,00 \%$ & $0,00 \%$ & $0,00 \%$ \\
\hline Leadership & $92,68 \%$ & $6,10 \%$ & $0,00 \%$ & $0,00 \%$ & $0,00 \%$ & $1,22 \%$ \\
\hline Hachman\&Oldman motivation model & $68,29 \%$ & $30,49 \%$ & $0,00 \%$ & $0,00 \%$ & $0,00 \%$ & $1,22 \%$ \\
\hline Hersey \& Blanchard leadership model & $63,41 \%$ & $36,59 \%$ & $0,00 \%$ & $0,00 \%$ & $0,00 \%$ & $0,00 \%$ \\
\hline $\begin{array}{l}\text { What do you think about evaluating your classmates } \\
\text { accurately with responsability about your decission } \\
\text { consequences? }\end{array}$ & Srongly agree & Agree & Neutral & Disagree & $\begin{array}{l}\text { Strogly } \\
\text { disagree }\end{array}$ & NA \\
\hline \begin{tabular}{|c|}
$\begin{array}{c}\text { To take a decission that affect people you know has } \\
\text { been actually a hard task? }\end{array}$ \\
\end{tabular} & $96,34 \%$ & $3,66 \%$ & $0,00 \%$ & $0,00 \%$ & $0,00 \%$ & $0,00 \%$ \\
\hline Do you have preferred not evaluate your classmates? & $98,78 \%$ & $1,22 \%$ & $0,00 \%$ & $0,00 \%$ & $0,00 \%$ & $0,00 \%$ \\
\hline $\begin{array}{c}\text { Did you Think to take decissions with responsabiity } \\
\text { over the consequiences was easyer? }\end{array}$ & $100,00 \%$ & $0,00 \%$ & $0,00 \%$ & $0,00 \%$ & $0,00 \%$ & $0,00 \%$ \\
\hline It has been an interesting experience for you? & $67,07 \%$ & $28,05 \%$ & $0,00 \%$ & $0,00 \%$ & $0,00 \%$ & $4,88 \%$ \\
\hline \multicolumn{7}{|l|}{$\begin{array}{c}\text { Explain shortly what do yo have learned with this } \\
\text { experience }\end{array}$} \\
\hline & & & & & & \\
\hline & & & & & & \\
\hline & & & & & & \\
\hline & & & & & & \\
\hline & & & & & & \\
\hline
\end{tabular}

\subsection{Effective communication: verbal, nonverbal, written including e-mails and informs}

In the light on these answers we can conclude that the lack of knowledge over assertiveness and other communication tools is actually a reality. They recognise that all these contents are logical and that they usually apply some of them but without knowing they were applying assertive tools. On fact, students every year tell they did not pay attention to communication details, especially: nonverbal signs, message perception differences, rules to write e-mails and Berne transactions and plays.

The idea of utilizing live films to show situations and to propose changes on the dialogs in order to attain other concrete objectives has been very well accepted and assessed. But, overall presented works have reached a really good level clearly superior than we expected. 
Table 3. Students perception about communication contents and developed tools.

\begin{tabular}{|c|c|c|c|c|c|c|}
\hline Communication & Very Known & Known & $\begin{array}{l}\text { I had heard } \\
\text { something }\end{array}$ & $\begin{array}{c}\text { nearly } \\
\text { unknown }\end{array}$ & $\begin{array}{c}\text { totally } \\
\text { unknown }\end{array}$ & NA \\
\hline $\begin{array}{l}\text { Did you know anything about assertiveness before this } \\
\text { subject? }\end{array}$ & $0,00 \%$ & $0,00 \%$ & $4,88 \%$ & $0,00 \%$ & $95,12 \%$ & $0,00 \%$ \\
\hline $\begin{array}{l}\text { Did you know anything about transactional analysis before this } \\
\text { subject? }\end{array}$ & $0,00 \%$ & $0,00 \%$ & $0,00 \%$ & $0,00 \%$ & $100,00 \%$ & $0,00 \%$ \\
\hline & Strongly agree & Agree & Neutral & Disagree & $\begin{array}{l}\text { Strongly } \\
\text { disagree }\end{array}$ & NA \\
\hline $\begin{array}{l}\text { Do you consider assertiveness as an useful tool in your future } \\
\text { professional activity? }\end{array}$ & $86,59 \%$ & $13,41 \%$ & $0,00 \%$ & $0,00 \%$ & $0,00 \%$ & $0,00 \%$ \\
\hline $\begin{array}{l}\text { Did you consider transactional analysis as an useful tool for } \\
\text { improving your effectivity on interpersonal communication } \\
\text { processes? }\end{array}$ & $60,98 \%$ & $39,02 \%$ & $0,00 \%$ & $0,00 \%$ & $0,00 \%$ & $0,00 \%$ \\
\hline Do you consider interesting and useful class exercises? & $56,10 \%$ & $36,59 \%$ & $7,32 \%$ & $0,00 \%$ & $0,00 \%$ & $0,00 \%$ \\
\hline $\begin{array}{l}\text { Do yo consider interesting and useful class exercises over } \\
\qquad \text { videos? }\end{array}$ & $62,20 \%$ & $30,49 \%$ & $7,32 \%$ & $0,00 \%$ & $0,00 \%$ & $0,00 \%$ \\
\hline
\end{tabular}

\subsection{High performance teams, meetings, conflicts and negotiation.}

As it was expected this part of the subject has been the better evaluated since provides tools and concepts students think will be very relevant to their professional future and daily life. The lack of time makes difficult to deep as much it would be desirable. But what has been clearly achieved has been that all the students perceive the need of improving their abilities and capacities on these fields and spurred them to make courses specifics, especially about negociation.

Table 4. Student perception about their capacities upturn about contents.

\begin{tabular}{|c|c|c|c|c|c|c|}
\hline Questions about groups and conflicts & $\begin{array}{l}\text { Strongly } \\
\text { agree }\end{array}$ & Agree & Neutral & Disagree & $\begin{array}{l}\text { Strongly } \\
\text { disagree }\end{array}$ & NA \\
\hline $\begin{array}{l}\text { Do you actually understand that the conflict is not the problem, it is the way of } \\
\text { resolving it? }\end{array}$ & $73,17 \%$ & $23,17 \%$ & $2,44 \%$ & $0,00 \%$ & $0,00 \%$ & $1,22 \%$ \\
\hline $\begin{array}{l}\text { Do you consider yourself is now more capable of analysing conflict roots and applying } \\
\qquad \text { appropriate tools for controlling or resolving it? }\end{array}$ & $97,56 \%$ & $1,22 \%$ & $1,22 \%$ & $0,00 \%$ & $0,00 \%$ & $0,00 \%$ \\
\hline $\begin{array}{l}\text { Do you consider yourself are now more capable for participating with effectivity on } \\
\text { meetings and leading them before studying this subject? }\end{array}$ & $96,34 \%$ & $2,44 \%$ & $1,22 \%$ & $0,00 \%$ & $0,00 \%$ & $0,00 \%$ \\
\hline Do you consider at present yourself capable of preparing a work meeting? & $100,00 \%$ & $0,00 \%$ & $0,00 \%$ & $0,00 \%$ & $0,00 \%$ & $0,00 \%$ \\
\hline $\begin{array}{l}\text { Do you consider interesting the test results about your personal carecteristics for } \\
\qquad \text { working in group? }\end{array}$ & $97,56 \%$ & $1,22 \%$ & $0,00 \%$ & $0,00 \%$ & $0,00 \%$ & $1,22 \%$ \\
\hline $\begin{array}{l}\text { Do yo consider that knowing your Belbin test results will help you for working more } \\
\qquad \text { effectively on group in the future? }\end{array}$ & $98,78 \%$ & $0,00 \%$ & $0,00 \%$ & $0,00 \%$ & $0,00 \%$ & $1,22 \%$ \\
\hline Do you consider you have performed your capacity as negociator? & $80,49 \%$ & $12,20 \%$ & $4,88 \%$ & $0,00 \%$ & $0,00 \%$ & $2,44 \%$ \\
\hline $\begin{array}{l}\text { Do you consider you could apply the Harward Negociation Method in your daily } \\
\qquad \text { activities? }\end{array}$ & $73,17 \%$ & $12,20 \%$ & $13,41 \%$ & $0,00 \%$ & $0,00 \%$ & $1,22 \%$ \\
\hline
\end{tabular}


Managerial Skills for Engineers, an optative subject on last course of grade in the ETSIIV. Results of applying new methodologies for developing managerial skills

\subsection{Resume of individual abilities and capacities improvement.}

From trainers point of view this table can be considered the most relevant in order to improve the subject alongside next years. Deeping on the figures system modelling values have been a surprise year after year. Traditionally, this is a concept widely developed since it is one of the main activities of engineers, but students expose they need more examples for developing their abilities and capacities on this field. On fact the level of participation and discussion on class exercises has been a clear proof of this interest.

\section{Conclusions}

Summarizing, on the light of these results showed on the tables, the subject has been improving each year and the results from the point of view of students have been positive. The constraint more important is the length of only eight weeks. This kind of concepts and the own process of developing abilities and capacities need clearly more time of practice. Moreover, a similar subject would have to be developed at the end of Industrial Engineering Master that is the moment in which students really perceive the need of this contents, abilities and capacities since clearly they perceive they will need them a short time.

Table 5. Student perception about their capacities and abilities improvement.

\begin{tabular}{|c|c|c|c|c|c|}
\hline Score your assessment of your improvement on: & Very poor & Poor & Fair & Good & Very good \\
\hline Interpersonal communication & $0,00 \%$ & $0,00 \%$ & $2,44 \%$ & $24,39 \%$ & $73,17 \%$ \\
\hline Interpreting non-verbal communication & $0,00 \%$ & $19,51 \%$ & $28,05 \%$ & $43,90 \%$ & $8,54 \%$ \\
\hline Written communication & $0,00 \%$ & $8,54 \%$ & $20,73 \%$ & $46,34 \%$ & $24,39 \%$ \\
\hline e-mail communication & $0,00 \%$ & $0,00 \%$ & $19,51 \%$ & $80,49 \%$ & $0,00 \%$ \\
\hline System modelling & $0,00 \%$ & $0,00 \%$ & $19,51 \%$ & $60,98 \%$ & $19,51 \%$ \\
\hline Negotiation capabilities & $0,00 \%$ & $7,32 \%$ & $24,39 \%$ & $68,29 \%$ & $0,00 \%$ \\
\hline To become an efficient team member & $0,00 \%$ & $14,63 \%$ & $21,95 \%$ & $56,10 \%$ & $7,32 \%$ \\
\hline Preparing effective meetings & $0,00 \%$ & $0,00 \%$ & $9,76 \%$ & $60,98 \%$ & $29,27 \%$ \\
\hline Applying assertive tools on daily life & $0,00 \%$ & $0,00 \%$ & $7,32 \%$ & $60,98 \%$ & $31,71 \%$ \\
\hline Applying assertive tools on your future professional life & $0,00 \%$ & $0,00 \%$ & $31,71 \%$ & $47,56 \%$ & $20,73 \%$ \\
\hline
\end{tabular}




\section{References}

Abbey, D.S. (1973). Transactional Analysis: Social and Communication Training. Human Development Institute.

Churchman, D. (1995). Negotiation: Process, Factors, Theory. University Press of America.

Coleman, P.T., Deutch, M., Marcus, E. (2014). The Handbook of Conflict Resolution. Theory and Practice. John Willey and Sons

Fisher, R. \& Ury, W. (2012). Getting to Yes. Negotiating on agreement without giving in. Random House.

Lamber, J., Myers, S. (1999). 50 Activities for Conflict Resolution. Group Learning and Self Development Exercises. HRD. Press.

Page, K. (1995). Assertiveness Skills Training. A sourcebook of activities. Ed. Kogan Page.

Pfeiffer, R. (1999). Relationships: assertiveness skills. Growth Publishing.

Phillips, A. (2003). Assertiveness and the Manager's Job. Radcliff Press.

Potts, C, \& Potts, S. (2013). Assertiveness: How to be strong in every situation. John Willey and Sons.

Raiffa, H. (2003. The Art and Science of Negotiation. Harvard University Press.

Robbins, S.P., Coulter, M. K. (2008). Organizational Behaviour. Pearson Prentice Hall.

Robbins, S.P., Judge, T. \& Judge, T.A. (2012). Management. Pearson Prentice Hall.

Sing, B.D. (2008). Managing conflict and negotiation. Excel Books.

Tubb, S.L., Carter, R.M. (1978). Shared Experiences in Human Communication. Hayden Book Company. 